\title{
Studies on Measles Vaccination in Nigerian Children
}

\author{
R. G. HENDRICKSE,* M.D., F.R.C.P.ED.; D. MONTEFIORE, M.D., DIP.BACT. \\ P. M. SHERMAN,* M.B., B.S., D.C.H. ; H. M. VAN DER WALL,* L.M.S., D.P.H., T.D.D.
}

Brit. med. F., 1964, 1, 470-474

Measles is a severe disease in Nigerian children. Over one thousand cases of measles are seen each year at the University College Hospital, Ibadan, and approximately $3 \%$ of the patients die as a result of the infection. In addition, a high proportion of the surviving children show marked debility for a long while after the illness. These findings are similar to those of Gans et al. (1961) and of Morley et al. (1963), who reported slightly higher mortality rates. Predominantly young children are infected, as can be judged by the occurrence of neutralizing antibodies in the sera of nearly $100 \%$ by the age of 5 years (D. M., unpublished data).

It is clear that under these circumstances there is an urgent need for a safe and effective means of preventing the disease. In Ibadan the first trials of live measles vaccines were undertaken in 1960. In this study three live attenuated measles vaccines were used, and were found to produce satisfactory antibody responses; but the frequency and severity of the reactions which followed vaccination were such as to preclude their general use (Collard et al., 1961).

Further studies have since been made of three new live measles vaccines, Nos. 14,16 , and 20 , with a view to determining their reactogenicity and suitability for general use. In one of these studies vaccine $4 \mathrm{~A}$, which was one of those used in the trials in 1960, was also included for comparison.

We report here the results of these studies.

\section{The General Plan}

Four trials were made during the period October 1962 to June 1963. A total of 712 children were included in these trials, and 533 of these received one or other measles vaccine. The remaining children served as controls, and were given poliomyelitis vaccine. In all trials children known to be immune and those defaulting from the regular follow-up have been excluded from the analysis of results. Table I summarizes

TABLE I.-Numbers of Children Accepted Into Vaccine Trials

\begin{tabular}{|c|c|c|c|c|c|c|c|c|}
\hline \multirow[b]{2}{*}{ Trial } & \multirow{2}{*}{$\begin{array}{l}\text { No. } \\
\text { in } \\
\text { Trial }\end{array}$} & \multirow[b]{2}{*}{$\begin{array}{l}\text { M.V. } \\
\text { Group* }\end{array}$} & \multirow{2}{*}{$\begin{array}{l}\text { Control } \\
\text { Group } t\end{array}$} & \multicolumn{2}{|c|}{ Defaulters } & \multirow{2}{*}{$\begin{array}{c}\text { Known } \\
\text { Immunes }\end{array}$} & \multicolumn{2}{|c|}{$\begin{array}{l}\text { No. Included } \\
\text { in Results }\end{array}$} \\
\hline & & & & $\begin{array}{l}\text { M.V. } \\
\text { Group }\end{array}$ & $\begin{array}{l}\text { Control } \\
\text { Group }\end{array}$ & & $\begin{array}{l}\text { M.V. } \\
\text { Group }\end{array}$ & $\begin{array}{l}\text { Contro } \\
\text { Groups }\end{array}$ \\
\hline $\begin{array}{l}\mathbf{A} \\
\mathbf{B} \\
\mathbf{C} \\
\mathbf{D}\end{array}$ & $\begin{array}{r}95 \\
108 \\
150 \\
359\end{array}$ & $\begin{array}{r}65 \\
108 \\
104 \\
256\end{array}$ & $\begin{array}{r}30 \\
0 \\
46 \\
103\end{array}$ & $\begin{array}{r}2 \\
0 \\
19 \\
106\end{array}$ & $\begin{array}{r}0 \\
0 \\
12 \\
46\end{array}$ & $\begin{array}{r}13 \\
0 \\
6 \\
13\end{array}$ & $\begin{array}{r}53 \\
108 \\
79 \\
137\end{array}$ & $\begin{array}{l}27 \\
34 \\
57\end{array}$ \\
\hline Total & 712 & 533 & 179 & 127 & 58 & 32 & 377 & 118 \\
\hline
\end{tabular}

* Children given measles vaccine. †Children given poliomyelitis vaccine.

the number of children participating in the trials, including the defaulters and those known to be immune. Reports have been obtained from the mothers of all except 15 of the defaulters. The reasons for failure to attend were generally a misunderstanding about the dates for reporting, or, because the child was well, the mother did not consider it necessary to come back. There is no reason to suppose that the children who failed to

* From the Departments of Paediatrics, Bacteriology, and Preventive and Social Medicine, University of Ibadan. attend for follow-up fared any worse than those attending regularly.

Trial A.-A comparison of vaccines 14 and 16 with a control. Assessments were made on 29 children given vaccine 14, 24 given vaccine 16, and 27 in the control group.

Trial B.-An acceptability trial using vaccine 16 . A total of 108 children were vaccinated; 43 were children of academic staff and 65 were children of ancillary and domestic staff.

Trial C.-A comparison of vaccines 4A, 16, and 20 with a control. Assessments were made on 17 children given vaccine $4 \mathrm{~A}$, 38 given vaccine 16,24 given vaccine 20 , and 34 in the control group.

Trial D.-A comparison of vaccine 20 with a control. Assessments were made on 137 children given vaccine 20 , and 57 children in the control group.

\section{Vaccines}

Vaccine 4A was derived from Edmonston $\mathrm{B}$ strain and has been fully described previously (Goffe and Laurence, 1961). Vaccines 16 and 20 were also derived from this strain but at further passage-levels in chick-embryo-tissue culture or embryonated eggs. Vaccine 14 was produced by further passage of vaccine 3C, described by Goffe and Laurence, 1961, which was derived from the Edmonston A strain.

All the vaccines were freeze-dried, and were reconstituted immediately before use. The virus content of the vaccines reconstituted and titrated after the vaccination sessions were: vaccine $4 \mathrm{~A}, 10^{3.0} \mathrm{TCD}_{50}$ per $\mathrm{ml}$; 位cine $14,10^{3.0} \mathrm{TCD}_{50}$ per $\mathrm{ml}$.; vaccine $16,10^{3.5} \mathrm{TCD}_{50}$ per $\mathrm{ml}$; and vaccine 20 , $20^{2.7} \mathrm{TCD}_{50}$ per $\mathrm{ml}$.

In each case $1 \mathrm{ml}$. of the reconstituted vaccine was injected subcutaneously into the buttock. In all trials children in the "control" groups received $1 \mathrm{ml}$. of Salk-type poliomyelitis vaccine subcutaneously. The normal immunization course with this vaccine was continued at a later date.

\section{Methods}

The conduct of the comparative trials A, C, and D was the same except for a few details which are indicated in the account of each separate trial. In each of these trials a group of children was given Salk-type poliomyelitis vaccine and acted as controls. Children were randomly allocated to the measlesvaccine groups or the control group.

Healthy children between the age of 6 months and 2 years were accepted for vaccination, and these included children who although undernourished were otherwise well. All children not on routine antimalarial therapy were given a curative dose of chloroquine sulphate on the day of vaccination and a weekly dose of pyrimethamine throughout the trial period of 28 days.

On the day of vaccination all children had a history taken, their weight and temperature were recorded, and a full physical examination was made. A standard card was used for these records and for the findings made during the follow-up period.

After vaccination each child was seen daily during the period when reactions were expected; their rectal temperatures were 
taken and notes made of any rash, cough, coryza, conjunctivitis, diarrhoea, convulsions, or other symptoms. Children were seen on one or two occasions after the "reaction period," one of these being on the 21st or 28th day after vaccination, when post-vaccination sera were taken. Throughout the trial period medical attention was available daily and any children who were in any way unwell were appropriately treated.

The examination on the day of vaccination was carried out by two physicians (P.S. and H.W.), one of whom (P.S) was subsequently responsible for the post-vaccination examinations, with occasional assistance from another physician in the larger trials. The observers were kept unaware of the vaccination status of each child until the follow-up was completed. A final assessment of the clinical reaction of each child to vaccination was made after the 14 th post-vaccination day. This assessment was made by the observer (P.S.) in consultation with the senior physician (R.G.H.), taking into consideration the general condition of the child, its temperature, and the occurrence of cough, coryza, conjunctivitis, diarrhoea, convulsions, and other symptoms.

Serum samples were taken from children as indicated in the account of each separate trial and tested for neutralizing antibodies to measles virus. Hep- 2 tissue cultures were used and $0.2-\mathrm{ml}$. volumes of serum dilution and virus suspension containing $30-300 \mathrm{TCD}_{50}$ measles virus. Neutralization was carried out for one hour at room temperature.

\section{Trial A. Comparison of Vaccines 14 and 16 with a Control}

After vaccination each child was seen daily from the 5 th to 14 th days inclusive, and again on the 21st and 28th days. All children had pre- and post-vaccination serum samples taken.

TABLE II.-Trial A. Clinical Responses After Vaccination

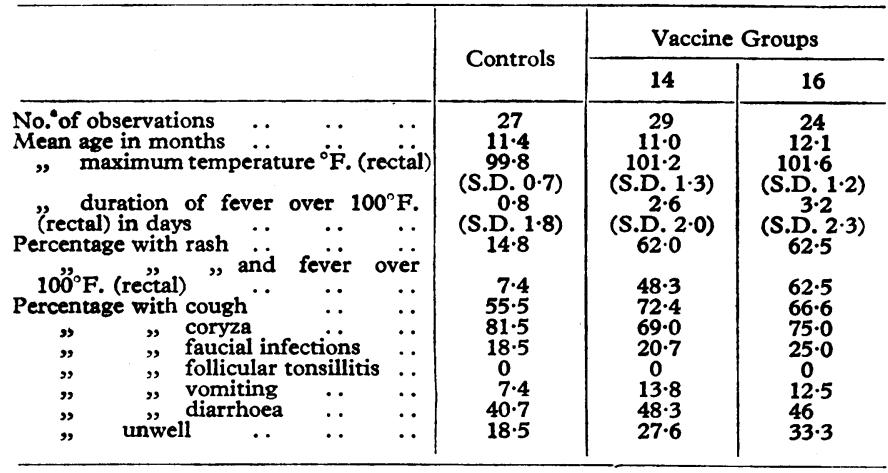

TABle III.-Trial A. Criteria for Assessing Children as "Unwell"

\begin{tabular}{|c|c|c|c|c|c|}
\hline \multicolumn{2}{|c|}{$\begin{array}{c}\text { Controls } \\
\text { (27 Children) }\end{array}$} & \multicolumn{2}{|c|}{$\begin{array}{c}\text { Vaccine } 16 \\
\text { (24 Children) }\end{array}$} & \multicolumn{2}{|c|}{$\begin{array}{c}\text { Vaccine } 14 \\
\text { (29 Children) }\end{array}$} \\
\hline Diagnosis & No. & Diagnosis & No. & Diagnosis & No. \\
\hline $\begin{array}{lll}\begin{array}{ll}\mathbf{A}+\mathbf{D}+\mathbf{M} \\
\mathbf{A}+\mathbf{E}+\mathbf{J}\end{array} & \ldots & \cdots \\
\mathbf{A}+\mathbf{P} & \cdots & \cdots \\
\mathbf{D}+\mathbf{E} & \cdots & \cdots \\
\mathbf{E}+\mathbf{J} & \cdots & \cdots\end{array}$ & $\begin{array}{l}1 \\
1 \\
1 \\
1 \\
1\end{array}$ & $\begin{array}{l}\mathrm{A}+\mathrm{D}+\mathrm{E}+\mathrm{G} \\
\mathrm{A}+\mathrm{D} \\
\mathrm{A}+\mathrm{H} \\
\mathrm{E}+\mathrm{I} \\
\mathbf{G}\end{array}$ & $\begin{array}{l}1 \\
2 \\
1 \\
1 \\
1 \\
1\end{array}$ & $\begin{array}{l}\mathbf{A} \\
\mathrm{A}+\mathrm{D} \\
\mathrm{D}+\mathrm{E}+\mathrm{H} \\
\mathrm{E} \\
\mathbf{I} \\
\mathbf{O}\end{array}$ & $\begin{array}{l}1 \\
2 \\
1 \\
2 \\
1 \\
1\end{array}$ \\
\hline $\begin{array}{l}\text { Total unwell } \\
\text { No. given specific } \\
\text { treatment }\end{array}$ & $\begin{array}{l}5 \\
5\end{array}$ & & $\begin{array}{l}7 \\
5\end{array}$ & & $\begin{array}{l}8 \\
7\end{array}$ \\
\hline
\end{tabular}

Criteria for "unwell ": $A=$ Faucial infections. $B=$ Follicular tonsillitis. $C=$ Cough. $\mathrm{D}=$ Vomiting. $\mathrm{E}=$ Diarrhoea. $\mathrm{F}=$ Otitis media. $\mathrm{G}=$ Convulsions aminosis. $M=$ Kwashiorkor. $\mathrm{N}=$ Skin sepsis. $\mathrm{O}=$ Pyoarthritis. $\mathrm{P}=$ Pertussis $\mathbf{Q}=$ Undiagnosed. $\mathbf{R}=$ Death.

Results were obtained for 29 children given vaccine 14, 24 given vaccine 16, and 27 in the control group. The findings, given in Table II, show that as regards post-vaccination reactions there was little difference between the two measles vaccines, but the children receiving the vaccines showed higher temperatures than those in the control groups. In addition, the duration of fever over $100^{\circ} \mathrm{F} .\left(37.8^{\circ} \mathrm{C}\right.$.) was considerably longer in the measles vaccine groups than in the control group. There was little difference in the incidence of diarrhoea, faucial infections, cough, or vomiting between either of the vaccine groups or the control group. A somewhat higher proportion of those children receiving measles vaccine were considered to be clinically unwell compared with those receiving poliomyelitis vaccine. The reasons for judging children to be unwell are given for each individual case in Table III.

Table IV shows the range of temperatures recorded in each group. If one regards a fever of $103^{\circ} \mathrm{F}$. $\left(39.4^{\circ} \mathrm{C}\right.$.) or over as representing a "severe" febrile response, it will be seen that none of the children in the control group, $12.5 \%$ of those given vaccine 16 , and $13.8 \%$ of those given vaccine 14 , fall into this category.

TABLE IV.-Trial A. Maximum Temperature Responses After Vaccination

\begin{tabular}{|c|c|c|c|c|}
\hline \multirow{2}{*}{$\underset{\text { (Rectal) }}{\operatorname{Max} .{ }^{\text {Temp. }}}{ }^{\circ} \mathrm{F}}$. & \multirow{2}{*}{${ }^{\circ} \mathrm{C}$. } & \multicolumn{3}{|c|}{ Percentage Incidence } \\
\hline & & $\begin{array}{l}\text { Control Group } \\
\text { (27 Children) }\end{array}$ & $\begin{array}{c}\text { Vaccine } 16 \\
\text { (24 Children) }\end{array}$ & $\begin{array}{c}\text { Vaccine 14 } \\
\text { (29 Children) }\end{array}$ \\
\hline $\begin{array}{l}<100 \\
100-101 \cdot 4 \\
101 \cdot 5-102 \cdot 9 \\
103-104 \cdot 4 \\
104 \cdot 5-\quad \ldots\end{array}$ & $\begin{array}{l}<37 \cdot 8 \\
37 \cdot 8-38 \\
38 \cdot 5-39 \cdot 35 \\
39 \cdot 4-40 \cdot 2 \\
40 \cdot 2-\end{array}$ & $\begin{array}{r}63 \\
33 \\
4 \\
0 \\
0\end{array}$ & $\begin{array}{r}8 \cdot 5 \\
37 \cdot 5 \\
41 \cdot 5 \\
12 \cdot 5 \\
0\end{array}$ & $\begin{array}{c}24 \cdot 2 \\
41 \cdot 4 \\
20 \cdot 6 \\
13 \cdot 8 \\
0\end{array}$ \\
\hline
\end{tabular}

All the sera taken from non-immune children given either measles vaccine 14 or 16 showed a fourfold or greater increase in neutralizing antibody titre. The pre-vaccination antibody titre was less than $1: 4$ in each case; the post-vaccination geometric mean titre was $1: 62$ for vaccine 14 and $1: 116$ for vaccine 16 .

\section{Trial B. Acceptability of Vaccine 16}

Although it was clear from the results of Trial A that a more attenuated vaccine would be desirable for general use, it was thought worth while to do an acceptability trial, using one of the vaccines from Trial $A$, in case a more attenuated vaccine did not become available. Vaccine 16 was selected for this purpose.

This study was conducted within the University of Ibadan, where parents were invited to have their children vaccinated, provided the children were healthy and had no history of measles. The 108 children vaccinated fell in two groupsthose of academic staff (Nigerian and expatriate) and those of the ancillary and domestic staff (all of whom were Nigerian). The cinildren were examined on the day of vaccination, and medical attention was available, if required, for the next 28 days. Mothers reported on the vaccination reactions they observed on or after the 14 th post-vaccination day. Academic staff mothers were asked to fill in a questionary relating to vaccination reactions and whether or not they regarded the vaccine

TABLE V.-Trial B. Acceptability Trial Using Vaccine 16

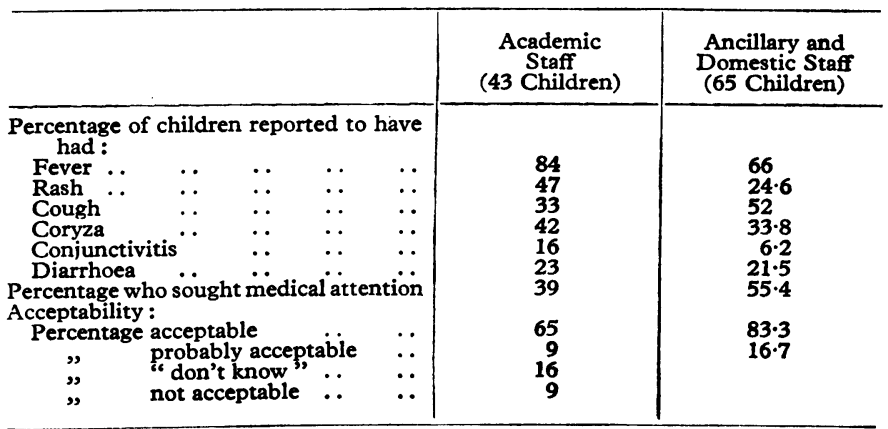


as acceptable. They were also given an interview, where they were free to expand their answers to the questionary. This method of reporting was not suitable for the "junior" staff mothers, where the interview only was employed.

The available results, summarized in Table V, show that $65 \%$ of academic staff mothers and $83 \%$ of junior staff parents thought the vaccine acceptable. As might be expected, rather more of the academic staff parents detected fever among their children than did the junior staff parents, and fewer academic staff children suffered from coughs than did junior staff children.

Data on the degree of protection afforded by this vaccine will become available over the course of the next two years.

\section{Trial C. Comparison of Vaccines 4A, 16, and 20 with a Control}

When vaccine 20 became available it was decided to conduct a trial including two of the older vaccines as a basis for assessing the degree of attenuation of the new vaccine. For this purpose vaccine $4 \mathrm{~A}$, which had been used in 1960, and vaccine 16, which had been used in Trials $A$ and $B$, were employed.

Results were obtained for 17 children given vaccine $4 \mathrm{~A}$, 38 given vaccine 16,24 given vaccine 20 , and 34 in the control group. The first 30 children accepted in the trial were seen daily from the 7 th to the 14 th post-vaccination day inclusive ; the remaining children were seen on the 5th day, then daily from the 8 th to the 12 th day inclusive, and again on the 15 th and 28 th days. The first 30 children also had pre-vaccination serum samples taken, but only one in three of the remaining children had samples taken before vaccination. Post-vaccination serum samples were taken from those children given vaccine 20 who had had pre-vaccination serum samples taken: second samples were not taken from children given the other vaccines, as in these cases the antibody response to the vaccines was already well known.

The results are given in Table VI. It will be seen that the mean maximum temperatures recorded after vaccines $4 \mathrm{~A}$ and 16 are similar to those found for vaccines 14 and 16 in Trial $A$ (Table II). The mean duration of fever after vaccines $4 \mathrm{~A}$ and

\section{TABLE VI.-Trial C. Clinical Responses After Vaccination}

\begin{tabular}{|c|c|c|c|c|}
\hline & \multirow{2}{*}{ Controls } & \multicolumn{3}{|c|}{ Vaccine Groups } \\
\hline & & 20 & 16 & $4 \mathrm{~A}$ \\
\hline 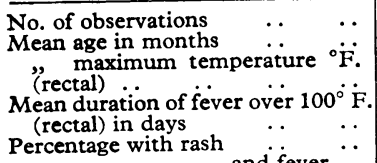 & $\begin{array}{c}34 \\
11 \cdot 0 \\
100 \cdot 4 \\
(\text { S.D. } 1 \cdot 3) \\
0.9 \\
(\text { S.D. } 1 \cdot 3) \\
2.9\end{array}$ & $\begin{array}{c}24 \\
10 \cdot 4 \\
100 \cdot 3 \\
\text { (S.D. } 0 \cdot 6) \\
1 \cdot 8 \cdot \\
\text { (S.D. } 2 \cdot 3) \\
16 \cdot 7\end{array}$ & $\begin{array}{c}38 \\
10 \cdot 3 \\
101 \cdot 4 \\
(\mathrm{~S} . \mathrm{D} \cdot 1 \cdot 6) \\
2 \cdot 7 \\
(\mathrm{~S} . \mathrm{D} \cdot 2 \cdot 4) \\
50 \cdot 0\end{array}$ & $\begin{array}{l}17 \\
10 \cdot 6 \\
101 \cdot 1 \\
\text { S.D. } 1 \cdot 4 \\
2 \cdot 5 \\
\text { S.D. } 2 \cdot 3 \cdot 3 \\
35 \cdot 3\end{array}$ \\
\hline 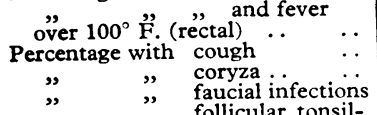 & $\begin{array}{r}2.9 \\
61.7 \\
56 \cdot 0 \\
20 \cdot 6\end{array}$ & $\begin{array}{l}16.7 \\
50.0 \\
54.0 \\
12.5\end{array}$ & $\begin{array}{l}50.0 \\
60.5 \\
74.0 \\
42.0\end{array}$ & $\begin{array}{l}35.3 \\
53.0 \\
41 \cdot 0 \\
17 \cdot 6\end{array}$ \\
\hline litis $\quad . " \quad$ follicular tonsil- & 0 & & & \\
\hline $\begin{array}{l}\text { Percentage with vomiting } \\
\# \quad \text { unwiarrhoea } \\
\# \quad \text { unwell }\end{array}$ & $\begin{array}{l}11 \cdot 7 \\
50.0 \\
23 \cdot 5\end{array}$ & $\begin{array}{l}16 \cdot 7 \\
29.0 \\
25 \cdot 0\end{array}$ & $\begin{array}{l}16 \\
44 \cdot 7 \\
55 \cdot 3\end{array}$ & $\begin{array}{c}0 \\
41 \cdot 0 \\
47 \cdot 0\end{array}$ \\
\hline
\end{tabular}

16 are also similar. With regard to the other criteria, such as cough, coryza, faucial infections, vomiting, and diarrhoea, vaccine 16 produced results similar to those which it produced in Trial A, and seemed to be slightly less attenuated than the older vaccine $4 \mathrm{~A}$. In addition there was a tendency for more children to be judged clinically unwell after vaccine 16 than after vaccine $4 \mathrm{~A}$.

The findings with vaccine 20 , however, were very different. The mean maximum temperature after this vaccine was the same as in the control group. None of the children given vaccine 20 showed a "severe" febrile response of $103^{\circ} \mathrm{F}$. $\left(39.4^{\circ}\right.$ C.) (rectal) or over, whereas $8.8 \%$ of children in the control group, $18.4 \%$ of those given vaccine 16 , and $11.8 \%$ of those given vaccine $4 \mathrm{~A}$ developed these high temperatures (see Table VII). On all other criteria the group of children given vaccine 20 compared favourably with the children in the control group, and in addition the proportion of children regarded as "unwell" was almost the same in the vaccine 20 group as in the control group. The reasons for assessing individual children as "unwell" are given in Table VIII.

\begin{tabular}{|c|c|c|c|c|}
\hline \multirow{2}{*}{$\underset{\text { (Rectal) }}{\operatorname{Max} . \text { Temp. }}{ }^{\circ} \mathrm{F}}$. & \multicolumn{4}{|c|}{ Percentage Incidence } \\
\hline & $\begin{array}{l}\text { Control Group } \\
\text { (34 Children) }\end{array}$ & $\begin{array}{c}\text { Vaccine 20 } \\
\text { (24 Children) }\end{array}$ & $\begin{array}{c}\text { Vaccine } 16 \\
\text { (38 Children) }\end{array}$ & $\begin{array}{c}\text { Vaccine 4A } \\
\text { (17 Children) }\end{array}$ \\
\hline $\begin{array}{l}<100 \\
100-101 \cdot 4 \\
101 \cdot 5-102 \cdot 9 \\
103-104 \cdot 4 \\
104 \cdot 5-\end{array}$ & $\begin{array}{r}41 \cdot 1 \\
44 \cdot 1 \\
6 \cdot 0 \\
6 \cdot 0 \\
2 \cdot 8\end{array}$ & $\begin{array}{c}8 \cdot 3 \\
87 \cdot 5 \\
4 \cdot 2 \\
0 \\
0\end{array}$ & $\begin{array}{r}15 \cdot 8 \\
42 \cdot 1 \\
23.7 \\
15 \cdot 8 \\
2.6\end{array}$ & $\begin{array}{r}23 \cdot 5 \\
41 \cdot 2 \\
23 \cdot 5 \\
5.9 \\
5.9\end{array}$ \\
\hline
\end{tabular}

TABLe VIII.-Trial C. Criteria for Assessing Children as "Unwell"

\begin{tabular}{|c|c|c|c|c|c|c|c|c|}
\hline \multicolumn{3}{|c|}{$\begin{array}{c}\text { Controls } \\
\text { (34 Children) }\end{array}$} & \multicolumn{2}{|c|}{$\begin{array}{c}\text { Vaccine } 20 \\
\text { (24 Children) }\end{array}$} & \multicolumn{2}{|c|}{$\begin{array}{c}\text { Vaccine } 16 \\
\text { (38 Children) }\end{array}$} & \multicolumn{2}{|c|}{$\begin{array}{l}\text { Vaccine 4A } \\
\text { (17 Children) }\end{array}$} \\
\hline Diagnos & & No. & Diagnosis & No. & Diagnosis & No. & Diagnosis & No. \\
\hline $\begin{array}{ll}\mathbf{A} & \ddot{\mathrm{A}} \\
\mathrm{A} & \mathrm{E}+\ddot{\mathrm{N}} \\
\mathrm{H} & \cdots \\
\mathrm{K} & \cdots \\
\mathrm{R} & \cdots\end{array}$ & $\begin{array}{l}\ldots \\
\cdots \\
\cdots \\
\cdots\end{array}$ & $\begin{array}{l}2 \\
1 \\
2 \\
1 \\
1 \\
1\end{array}$ & $\begin{array}{l}A+C+N \\
A+E+N \\
C+D+E \\
C \\
D \\
F\end{array}$ & $\begin{array}{l}1 \\
1 \\
1 \\
1 \\
1 \\
1\end{array}$ & $\begin{array}{l}\mathrm{A} \\
\mathrm{A}+\mathrm{D} \\
\mathrm{A}+\mathrm{E} \\
\mathrm{D} \\
\mathrm{E} \\
\mathrm{E}+\mathrm{D} \\
\mathrm{F} \\
\mathrm{H} \\
\mathrm{H}+\mathbf{A} \\
\mathrm{I} \\
\mathrm{P}\end{array}$ & $\begin{array}{l}3 \\
3 \\
5 \\
1 \\
2 \\
1 \\
1 \\
2 \\
1 \\
1 \\
1\end{array}$ & $\begin{array}{l}\mathbf{A} \\
A+E \\
\mathbf{E} \\
\mathbf{N} \\
\mathbf{Q}\end{array}$ & $\begin{array}{l}2 \\
1 \\
2 \\
2 \\
1\end{array}$ \\
\hline $\begin{array}{l}\text { Total unwel } \\
\text { No. receivin } \\
\text { specific } \\
\text { treatment }\end{array}$ & & 7 & & $\begin{array}{l}6 \\
1\end{array}$ & & $\begin{array}{l}21 \\
17\end{array}$ & & $\begin{array}{l}8 \\
4\end{array}$ \\
\hline
\end{tabular}

The clinical findings thus demonstrate a marked superiority of vaccine 20 over the other two vaccines. Indeed, children given vaccine 20 showed little in the way of symptoms which would not be expected on the basis of chance, as shown by the findings in the control group.

There was one death among the children in the control group: the mother reported that the child had had fever, diarrhoea, and vomiting, but it was not possible to determine the exact cause of death.

Pre- and post-vaccination serum samples were available from seven of the children given vaccine 20 . In all of these there was a fourfold or greater rise in measles neutralizing antibody titre following vaccination, the geometric mean titre of the post-vaccination samples being $1: 48$.

\section{Trial D. Comparison of Vaccine 20 with a Control}

The findings in Trial $\mathrm{C}$ were so encouraging with respect to vaccine 20 that it was decided to conduct a larger trial in which children given vaccine 20 would be compared directly with a control group given poliomyelitis vaccine. The general conduct of this trial was similar to the previous trials. After vaccination children were seen on either the 4 th, 5 th, or 6 th post-vaccination day, daily from the 8 th to the 12 th day inclusive, and again on the 15 th and 21 st post-vaccination days.

Pre- and post-vaccination serum samples were taken from one in three of the children given vaccine 20 .

The results obtained from 137 children given vaccine 20 and 57 in the control group are shown in Table IX. As in the previnus trial with vaccine 20 , the mean maximum temperature among the children receiving vaccine 20 was little different from 
TABLE IX.-Trial D. Clinical Responses After Vaccination

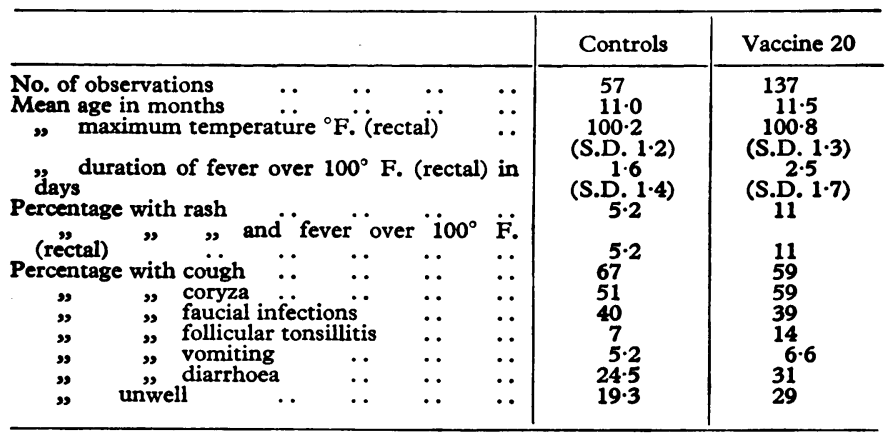

the mean maximum temperature among the control group. The mean duration of fever over $100^{\circ} \mathrm{F}$. $\left(37.8^{\circ} \mathrm{C}\right.$.) was, however, somewhat longer among the group receiving measles vaccine than among the control group. There was little difference between the vaccinated and control groups with regard to cough, coryza, vomiting, and diarrhoea. Both groups showed a high incidence of faucial infection: in the case of the vaccine 20 group, however, this took the form of a follicular tonsillitis more often than it did among the control group of children. This result is reflected in the higher incidence of children regarded as unwell in the vaccine group and is plainly demonstrated in Table $\mathrm{X}$, where reasons for classifying individual

TABLe X.-Trial D. Criteria for Assessing Children as "Unvell"

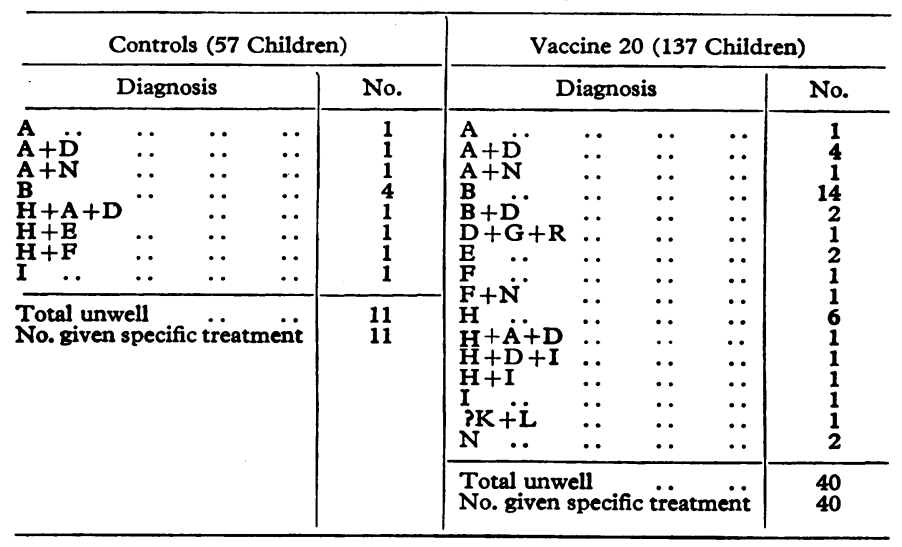

For criteria for " unwell" see foot of Table III.

children as unwell are listed. The increased severity of throat infections also accounted for the $10 \%$ incidence of "severe" febrile reactions of $103^{\circ} \mathrm{F}$. $\left(39.4^{\circ}\right.$ C.) or over among the vaccinated children as compared with the $5 \%$ incidence among the control group of children (see Table XI).

TABLE XI.-Trial D. Maximum Temperature Responses After Vaccination

\begin{tabular}{c|c|c}
\hline \multirow{2}{*}{\begin{tabular}{c|c} 
Max. Temp. \\
(Rectal)
\end{tabular}} & \multicolumn{2}{|c}{ Percentage Incidence } \\
\cline { 2 - 3 } & Vaccine 20 & Control Group \\
& (137 Children) & (57 Children) \\
\hline$<100$ & 27.0 & $42 \cdot 1$ \\
$100-101 \cdot 4$ & 49.6 & 47.4 \\
$101.5-102.9$ & $13 \cdot 2$ & $5 \cdot 2$ \\
$103-104 \cdot 4$ & 9.5 & 3.5 \\
$104 \cdot 5-$ & 0.7 & $1 \cdot 8$ \\
\hline
\end{tabular}

One child aged 11 months, who received vaccine 20 , became ill with severe diarrhoea and vomiting on the sixth day after vaccination. Signs of encephalitis developed later that day and the child died from encephalitis on the ninth day. The mother reported that the child had had diarrhoea and vomiting before vaccination, although she failed to mention this at the prevaccination examination. The early onset of symptoms tends to rule out the possibility of the measles vaccine being a causative factor in the case. Furthermore, histological and virological studies have failed to incriminate the vaccine, although they have not resulted in a definite diagnosis. It should be mentioned that encephalitis is not an uncommon cause of death among children attending the University College Hospital, Ibadan, but in the majority of cases the aetiology is never firmly established.

Paired sera were available from 68 children who received vaccine 20. Thirteen of them were found to be initially immune: of the remaining 535 all but four showed a fourfold or greater rise in antibody titre in the post-vaccination serum samples, giving a conversion rate of $93 \%$. The geometric mean titre of the post-vaccination samples was $1: 55$.

The results of this trial confirmed those of Trial C, that vaccine 20 was an efficient immunizing agent which provoked little reaction. Children given this vaccine, however, appeared more likely to develop follicular tonsillitis when infections of the upper respiratory tract were prevalent than did children in the control group.

\section{Summary and Conclusions}

In the series of trials reported here, 377 children between the ages of 6 and 20 months were each vaccinated with one of four different batches of live attenuated measles vaccines$4 A, 14,16$, or 20 -and their responses were compared with those of a further 118 children given poliomyelitis vaccine. The children were allocated to the measles-vaccine or control poliomyelitis-vaccine groups by an effective method of random allocation, and were closely followed up throughout the period when reactions to measles vaccine could be expected. Nearly all the observations were made by a single observer, who was kept unaware of the vaccination status of each child. Pre- and post-vaccination serum samples were taken from an adequate proportion of the children to determine the antibody responses. A further 108 children were given measles vaccine 16 to determine whether the reactions to the vaccine were acceptable to the parents.

Two children died during the present series of trials: one of these had been given poliomyelitis vaccine, and the other measles vaccine 20 . There was no evidence that vaccination played any part in these deaths. There is a high infant mortality in Ibadan as elsewhere in West Africa, available figures indicating a mortality rate of approximately $1 \%$ per month in the age-group we were studying (McGregor et al., 1961 ; H. Gillies, personal communication, 1963).

In the comparative trials it was found that vaccine 20 produced much milder reactions than did any of the other vaccines tested. In the majority of cases children given this vaccine developed a mild febrile response ranging up to $101.5^{\circ} \mathrm{F}$. $\left(38.6^{\circ}\right.$ C.) (rectal) which lasted for approximately two days. In other respects they did not differ from children given poliomyelitis vaccine, with the exception that when infections of the upper respiratory tract were prevalent those given the measles vaccine tended to develop follicular tonsillitis, while children given poliomyelitis vaccine more often developed only a mild pharyngitis. It is noteworthy that in the acceptability trial using vaccine 16 , which causes more severe reactions than does vaccine $20,83 \%$ of one group of mothers and $65 \%$ of another regarded the vaccine as acceptable.

Despite the high level of attenuation of vaccine 20 , it was found to result in the production of neutralizing antibodies in $93 \%$ of initially non-immune recipients. We consider that vaccine at this level of attenuation is suitable for use on a larger scale than we have undertaken to date.

We would like to thank Dr. S. O. Franklin and Dr. M. P. Otolorin, Ministry of Health and Social Welfare, Western Region;
Dr. G. S. Sethi, Medical Officer of Health, Ibadan ; and the staff 
of the Health Office and of the Inalende Maternity Centre for all the valuable assistance they afforded us during these trials. We would also like to thank members of the University of Ibadan Health Service, the Abadina Village Council, the health visitors of the School of Nursing, the Department of Social and Preventive Medicine, and the Department of Paediatrics, University of Ibadan, for their help.

The vaccines were kindly provided by the Wellcome Research Laboratories, and we thank Dr. T. M. Pollock and Dr. A. P. Goffe for their help and advice in the planning of these trials.
REFERENCES

Collard, P., Hendrickse, R. G., Montefiore, D., Sherman, P., van der Wall, H. M., Morley, D., Goffe, A. P., Laurence, G. D., and Pollock, T. M. (1961). Brit. med. F., 2, 1246.

Gans, B., Macnamara, F. N., Morley, D., Thomson, S. W., and Watt, A. (1961). W. Afr. med. F., 10, 253.

Goffe, A. P., and Laurence, G. D. (1961). Brit. med. F., 2, 1244.

McGregor, I. A., Billewicz, W. Z., and Thomson, A. M. (1961). Ibid., 2, 1661.

Morley, D., Woodland, M., and Martin, W. J. (1963). F. Hyg. (Lond.), 61, 115 .

\title{
Sulthiame in Treatment of Epilepsy
}

\author{
HUGH GARLAND,* T.D., M.D., F.R.C.P. ; DAVID SUMNER,* M.B., B.SC., M.R.C.P.
}

To claim to have evaluated a new anticonvulsant on the basis of 54 patients treated for no longer than 18 months would be wholly false. This study is presented rather to draw attention to a drug which has received little notice in English medical literature and in particular to point out the hazards which may attend its use.

Sulthiame differs in structure from other anticonvulsants, being a sulphonamide with a closed-ring structure. Chemically it is $N$-(4'-sulphamoylphenyl)-butanesultam-(1-4) (tetrahydro-2-p-sulphamoyl-1, 2-thiazine 1, 1-dioxide), and has the structure :<smiles>NS(=O)(=O)c1ccc(N2CCCCS(=O)(=O)O2)cc1</smiles>

\section{Literature}

Pharmacological studies (Wirth et al., 1960) showed sulthiame to be highly effective in controlling electroconvulsive seizures in mice, having a far higher therapeutic index than phenobarbitone or diphenylhydantoin, although this difference was less marked in the control of attacks induced by leptazol ("metrazol"). Sulthiame is a weak carbonic anhydrase inhibitor and has a mild diuretic effect. It has a mild tranquillizing action in hamsters but no hypnotic effect. No evidence was found of gastric irritation nor of damage to the liver or central nervous system.

Following this work, a number of clinical reports have appeared initially from Germany but later from other countries. Fluegel et al. (1960) found the drug to be ineffective in minor epilepsy (petit mal), less effective than diphenylhydantoin in the control of major epilepsy (grand mal), but very effective in the control of temporal-lobe attacks. The only side-effects they noted were slight tiredness and lassitude, transitory paraesthesiae, dyspnoea, and occasional nausea. Skin reactions (unspecified) occurred in a few patients. The drug was given to 150 epileptics, in 84 of whom electroencephalograms had been performed; 31 of these showed focal patterns, 16 of which disappeared during sulthiame therapy.

Engelmeier (1960) treated 73 patients with sulthiame. Five proved to be intolerant, 28 were unaffected, and 40 were "improved." Of the five who were unable to tolerate the

* From the Department of Neurology, the General Infirmary at Leeds. drug, three were unable because of gastro-intestinal disturbances ("gastro-hepatic syndrome"), one because of oedema, and one because of dizziness and drowsiness. Other sideeffects were often seen, however, the commonest being paraesthesiae and milder gastro-intestinal disturbances.

Raffauf (1960) gave the drug to 81 epileptics with the following results: $60(74 \%)$ showed "marked improvement," $19(23 \%)$ were unchanged, and 2 (3\%) were worse. He gained the impression that the drug was most effective in the control of temporal-lobe attacks and claimed that side-effects were remarkably low, although in fact $25 \%$ complained of paraesthesiae and $10 \%$ of dyspnoea. One patient complained of angina of effort while taking sulthiame, and one had to stop the drug because she developed hypotension. Raffauf used a dose of $600 \mathrm{mg}$./day, combined with other anticonvulsants in $49(60 \%)$.

Haran (1962) treated 48 epileptics of long standing with sulthiame in a dose of $600 \mathrm{mg}$./day. In those patients who improved other anticonvulsants were withdrawn. Of the 40 who were followed up, $7(17.5 \%)$ were " much improved," 12 $(30 \%)$ were "improved," $20(50 \%)$ were unchanged, and 1 $(2.5 \%)$ became worse. Specific areas of improvement were found to be the reduction in irritability and aggression together with reduction in unmotivated violent or manic behaviour. The only side-effect noted was sleepiness in one patient.

Overvad (1962) reviewed 104 patients treated with sulthiame for from 5 to 15 months : 53 (52\%) remained free from attacks, but $10(19 \%)$ of these abandoned the drug because of side-effects or because it was ineffective. LaVeck et al. (1962) reported their experiences with 99 mentally retarded brain-damaged epileptics treated with sulthiame for six months : 32 remained fit-free for this period, but unlike previous authors they considered that toxicity was the limiting factor in the usefulness of the drug. Of the remainder 15 were " markedly improved" and 11 "improved." An average dose of $600 \mathrm{mg}$./day was used, but nevertheless lethargy, anorexia, or ataxia were found in 52 of their patients.

Ingram and Ratcliffe (1963), in a study of 37 children treated with sulthiame, found that $90 \%$ of those with hyperkinetic behaviour were improved or completely controlled, as were $80 \%$ of those with myoclonic jerks but only $45 \%$ of those with other forms of epilepsy ; 22 (60\%) showed side-effects, the commonest being hyperventilation (57\%), drowsiness $(14 \%)$, nausea or vomiting $(11 \%)$, and paraesthesiae $(8 \%)$. Bray and Bower (1963) treated 22 children with refractory epilepsy with sulthiame, and while $8(36 \%)$ improved con- 